\title{
Bird mixed-flocks and nuclear species in a tecoma savanna in the Pantanal
}

\author{
Amaral, PP. and Ragusa-Netto, J. ${ }^{\mathrm{b} *}$ \\ aPrograma de Pós Graduação em Ecologia e Conservação, Centro de Ciências Biológicas e da Saúde - CCBS, \\ Universidade Federal de Mato Grosso do Sul - UFMS, \\ CP 549, CEP 79070-900, Campo Grande, MS, Brazil \\ bDepartamento de Ciências Naturais, Centro Universitário de Três Lagoas - CEUL, \\ Universidade Federal de Mato Grosso do Sul - UFMS, \\ CP 210, CEP 79600-000, Três Lagoas, MS, Brazil \\ *e-mail: forpus@ceul.ufms.br \\ Received October 23, 2006 - Accepted July 18, 2007 - Distributed August 31, 2008
}

(With 4 figures)

\begin{abstract}
In bird mixed flocks, a prominent species, the so-called nuclear species, improves the cohesion and maintenance of the flocks, while other less conspicuous species are assumed as satellite. In this study we described the composition, as well as examined the existence of both nuclear and satellite species in mixed flocks of a savanna in the Pantanal. The observations were developed using three transects during the dry season of 2002. Bird species abundance and respective rate of participation in mixed flocks were surveyed by transects, while intraspecific sociality, communication, foraging maneuvers of species, and responses to predators were sampled by direct observations. These parameters were evaluated to distinguish nuclear from satellite species. We observed 41 bird mixed flocks, which included from 2 to 17 species of which Suiriri suiriri (Vieillot), one of the most abundant species, was present in most flocks, often represented by 2-4 individuals, whereas most other species occurred lone or in pairs. While foraging by acrobatic maneuvers $S$. suiriri often gave contact calls, as well as earlier giving alarm calls if faced with a risk of predation. In addition, $S$. suiriri always started mixed flocks movements. Conversely, most other species were silent and closely inspected the vegetation while foraging. Such species always followed $S$. suiriri and seldom gave contact calls. Hence, the conspicuous traits exhibited by S. suiriri, potentially, are exploited by the other bird species as cues, which are important references for bird mixed flock cohesion in a savanna in the southern Pantanal.
\end{abstract}

Keywords: bird mixed flocks, nuclear species, Pantanal, Suiriri suiriri, social behavior.

\section{Bandos mistos de aves e espécie nuclear em uma savana de ipês no Pantanal}

\section{Resumo}

Em bandos mistos de aves, a espécie nuclear possui características que promovem a coesão e manutenção dos bandos, enquanto espécies menos conspícuas são consideradas satélites. Este estudo teve como objetivos descrever a composição, bem como analisar a existência de espécies nucleares e satélites em bandos mistos em um tipo de savana do Pantanal Sul. As observações foram desenvolvidas ao longo de três trajetos durante a estação seca de 2002. A abundância das espécies e respectiva taxa de participação nos bandos mistos foram amostradas através de trajetos, enquanto dados sobre socialidade intra-específica, comunicação, manobras de forrageio e reação a predadores foram obtidos através de observações diretas. Esses parâmetros foram adotados como critérios, para distinguir espécies nucleares de satélites. Foram detectados 41 bandos mistos que incluíram de 2 a 17 espécies, sendo que Suiriri suiriri, uma das espécies mais abundantes na savana de ipês, esteve presente em praticamente todos os bandos, na forma de um par ou grupo de indivíduos que, regularmente, emitiam chamados de contato, enquanto forrageavam executando manobras acrobáticas. Também, emitiram chamados de alarme quando em risco de predação e foram seguidos pelas demais espécies durante os deslocamentos dos bandos. A maioria das outras espécies inspecionava a vegetação silenciosamente enquanto forrageavam, seguiam $S$. suiriri em seus deslocamentos e raramente emitiam chamados de contato. Portanto, características conspícuas exibidas por $S$. suiriri, potencialmente, são exploradas pelas demais espécies como importantes referências para coesão dos bandos mistos de aves em uma savana no Pantanal sul.

Palavras-chave: bandos mistos de aves, espécie nuclear, Pantanal, Suiriri suiriri, comportamento social. 


\section{Introduction}

Bird mixed flocks result from the cohesion of several foraging species which use a wide range of feeding niches from aerial fly catching to gleaning (Powell, 1985). As foraging advantages mixed flock members may increase prey capture success because, for example, they may copy successful foragers (Berner and Grubb, 1985; Waite and Grubb, 1988), and/or capture arthropods flushed by the flock movements through the vegetation (Hino, 1998). Also, while in mixed flocks, birds reduce predation risk due to the sum of surveillance effort of flock members (Powell, 1985; Hogstad, 1988; RagusaNetto, 2002).

Mixed flock members usually have been classed by their influence on flock cohesion (Powell, 1985; Hutto, 1994; Ragusa-Netto, 2002). The species which features widely contribute to the formation and maintenance of flocks are often assumed as nuclear. On the other hand, those species whose effect on flock cohesion is reduced or none have been classed as satellite (Powell, 1985; Dolby and Grubb, 1999; Ragusa-Netto, 2002). Among the major traits of nuclear species are: high occurrence and permanency in flocks (Powell, 1979; Hutto, 1994; Alves and Cavalcanti, 1996); enhanced sociality (Moynihan, 1962; Munn and Terborgh, 1979; Powell, 1985); conspicuous movements (Powell, 1985; Hutto, 1994); regularity of contact calls (Moynihan, 1962; Austin and Smith, 1972; Greig-Smith, 1978; Powell, 1985); front position during flock displacement (GreigSmith, 1978; Munn and Terborgh, 1979; Ragusa-Netto, 2002); enhanced perception of raptors (Munn and Terborgh, 1979; Ragusa-Netto, 2002); and reduced aggressive behavior (Powell, 1985; Hutto, 1994). In some mixed flocks more than one species may contribute to flock cohesion (Rand, 1954; Hutto, 1994). However, despite their importance in several bird mixed flocks, in some studies its presence was unclear (Winterbottom, 1949; Powell, 1979; Hutto, 1994).

Satellite species are less conspicuous, tend to be silent, forage alone or in pairs, usually closely focusing the vegetation (Munn and Terborgh, 1979; Powell, 1985; Hutto, 1994). Potentially, they are more vulnerable to predators, hence are likely to exploit nuclear species alertness and communication (Sullivan, 1984a,b; Hogstad, 1988; Ragusa-Netto, 2002).

Bird mixed flocks have been widely studied in the Neotropics, mainly in tall rain forests where they are richest in species (Powell, 1979; Munn and Terborgh, 1979; Stotz, 1993; Thiollay and Jullien, 1998). Mixed flocks from this area may occur either in the canopy or in the understory, and often include one nuclear and several satellite species, which are often represented by one or a pair of individuals (see reviews: Powell, 1985; Hutto, 1994). On the other hand, few studies focused mixed flocks in the Neotropical savannas. Bird mixed flocks from savannas are comparatively smaller and poorer in species composition, although each species are repre- sented by a pair or a group of individuals (Greig-Smith, 1978; Alves and Cavalcanti, 1996). Birds of these mixed flocks often forage within the canopy of trees and bushes or among grasses on the ground (Greig-Smith, 1978). Particularly, the nuclear species of these mixed flocks are both social and highly alert (Alves and Cavalcanti, 1996; Ragusa-Netto, 2000; 2002).

The Pantanal is the largest flood plain in the neotropics and one of the extensive areas dominated by savanna like habitats in South America (Pott and Pott, 1994). There, large and nomadic water birds figure as conspicuous components of bird communities (Sick, 1997). However, several other species, especially passerines, are resident in the savannas (pers. obs.). In the southern Pantanal, the 'tecoma savanna', dominated by Tabebuia aurea (Manso) B.et H., covers extensive areas and exhibits as major traits mediumsized trees within a matrix of grasses on seasonally flooded flat terrain (Pott and Pott, 1994). In this savanna, bird mixed flocks are common, conspicuous and easily observed, mainly during the prolonged dry season. Bird species forage either in the grasses or tecoma trees, and exhibit varied group size and frequency of contact calls (pers. obs.).

The heterogeneity of traits exhibited by birds within mixed flocks in the tecoma savanna is an interesting topic for an analysis on the existence of nuclear and satellite species. Taking in to account that different traits may explain the role of nuclear species (Goodale and Kotagama, 2005), and that in savannas, the nuclear species are the ones with greater sensitivity to the presence of predators (Alves and Cavalcanti, 1996; Ragusa-Netto, 2000, 2002), it is important to examine which traits potentially may be related to the existence of nuclear species in this savanna of the Pantanal. Therefore, in this study, we analyzed the structure and composition of bird mixed flocks in a tecoma savanna in the southern Pantanal. Particularly, we assessed the abundance and behavioral features (sociality, communication, foraging tactics, and predator avoidance) of species in order to relate these to the existence of nuclear and satellite species.

\section{Material and Methods}

\subsection{Study area}

This study was carried out in the Pantanal (Brazil), a flood plain of $140,000 \mathrm{~km}^{2}$. The vegetation is a mosaic of deciduous and gallery forests interspersed by savannas, open grassy areas and ponds, according to the topography, soil quality, and severity of annual floods (Pott and Pott, 1994). In the southern Pantanal, where the study site is located, the vegetation includes the dense Miranda river gallery forest, patches of deciduous forests interspersed with both palm (dominated by Copernicia alba Morong), and tecoma savanna (dominated by Tabebuia aurea), in which data collection was developed $\left(19^{\circ} 35^{\prime} \mathrm{S}\right.$ and $57^{\circ} 2^{\prime} \mathrm{W}$, altitude $\pm 100 \mathrm{~m}, 80-100 \mathrm{~km}$ east from Corumbá city, State of Mato Grosso do Sul). In the tecoma savanna, Tabebuia aurea trees are 4-8 $\mathrm{m}$ high, although some individuals 
may reach $12 \mathrm{~m}$. These trees develop on small mounds $( \pm 0.5-1.0 \mathrm{~m})$ where they remain free from floods. The mounds are interspersed with open grassy areas, in which common species are Panicum laxum Sw., Hymenachne amplexicaulis L. and Hemarthria altissima (Poir.) Stapf and C.E.Hubb. Individuals of Byrsonima orbignyana A. Juss. are often mixed with $T$. aurea, although in smaller number (Oliveira, 1993). Tabebuia aurea trees shed leaves just before flowering, generally from the middle to the late dry season. Annual rainfall is around $1,000 \mathrm{~mm}$, mostly from November to March (70-80\%, wet season). In this period average temperature is $27^{\circ} \mathrm{C}$, while in the dry season (April to October) average temperature is $20^{\circ} \mathrm{C}$, and in cold months (June-July) frosts may occur. In this area of the Pantanal, floods typically occur from January to March. During floods, standing water in the tecoma savanna is up to $1.0 \mathrm{~m}$ (Soriano, 1997).

\subsection{Abundance of species}

To sample bird abundance, and respective frequency of participation in bird mixed flocks, we used line transects, because this bird survey technique is suitable to count birds within large and uniform areas (Bibby et al., 1993). Bird species were surveyed to analyze the relationship between their relative abundance and frequency of participation in mixed flocks, instead of assessing their densities in the tecoma savanna. Therefore, we established three $2 \mathrm{~km}$-long transects $(1,000 \mathrm{~m}$ apart from each other), and at each transect 10 points at $200 \mathrm{~m}$ intervals were positioned from which one of us (P. P. Amaral, who carried out data collection) departed, walking, to detect birds. The selection of transect and respective departing point were done by lot without replacement. Monthly, from April to October 2002, these transects were walked from 6:00 AM to 6:00 PM hours, to complete 36 hours of observations (12 hours per transect). While walking, all individuals detected perched (with the aid of $8 \times 40$ binoculars) were recorded irrespective of the distance from the transect. To avoid double counting of the same individual, whenever at least one perched individual was detected its relative position was recorded on a map, which included the transect and parallel bands of $50 \mathrm{~m}$. Birds recorded at overlapping places were counted only once. The sum of all individuals recorded during the studied period was taken as an index of abundance of a given species.

\subsection{Sociality of species}

During the survey work birds were recorded simultaneously with respect to their social context. The bird was assumed to be foraging in a mixed-species flock if there was an individual of at least one other species located within $10 \mathrm{~m}$ of the subject bird and the two or more birds appeared to be together or following one another. The bird was assumed to be participating in a monospecific flock if all potential flock mates were of the same species. A bird was assumed as a solitary forager if no other bird within a radius of $10 \mathrm{~m}$ exhibited movements to join or follow the subject bird (Hutto, 1994).

\subsection{Behavioral traits of species}

$s$ " IRD MIXED mOOKS COMPOSITION $401 \mathrm{ND}$ MIXED flocks, the trails described above were also walked randomly. Then, once a mixed flock was detected, around five minutes was spent for the habituation of birds to the observer, who followed the mixed flocks for at least 30 minutes (an observation period), and recorded: a) species and individuals at every 30 minutes, b) the species which was in the front of conspicuous $(>20 \mathrm{~m})$ mixed flocks displacements, and c) all contact calls given by birds during a period of 10 minutes (always 15 minutes after the beginning of an observation period). The contact calls were distinguished from alarm calls due to the absence of evasive responses (Ragusa-Netto, 2000, 2002).

$s$ " IRD RESPONSES TOPFAATOR VOCES 7 E PEKORMED playbacks of the voices of potential predators common in the area (Glaucidium brasilianum (Gmelin) and Ramphastos toco Statius Muller), to record the responses of bird species to the potential risk of predation. The playback trials were conducted in all transects, so that eight trials were performed in one of them, while seven were performed in each of the two other (22 trials of each predator). We defined by lot without replacement the points to perform the playback trials, which occurred only if mixed flocks were absent. The points in which the playback trials were performed were at least $200 \mathrm{~m}$ from each other. This is an adequate distance to avoid the stimulation of the same birds from different points (Goodale and Kotagama, 2005), due to the small territory size (2-4 ha) of Neotropical passerines (Powell, 1989). Also, to avoid repeated stimulations of the same potential respondents, at a given transect, the playback trials were performed only during an observation period. Playbacks of predator voices were also performed when mixed flocks were active. These simulations were performed at the end of observation periods, when we recorded as responses both the time elapsed up to the approaching of a species, and performance of loud vocalizations and aggressive actions (e. g. fights). To avoid repeated stimulation of the same pool of respondents, at every transect, only one playback of each predator voice was performed.

s \&ORAGING TACICS \$ URNG OBSERVAIIONS ON MIXED flocks, the foraging tactics and respective maneuvers employed by every species at the attempts of capture of a prey were also recorded. The parameters focused were: height of the attempt of capture (estimated in meters) and type of maneuver, following Remsen and Robinson, 1990: a) sally-glean: fly and glean prey in a substrate; b) surface maneuvers: when perched, glean prey in substrate; c) hammer: hammer trunks and branches with beak, searching for prey; d) hover: hover in 
the air while a prey is take away from the substrate; e) sally: catch prey in the air; f) probe: investigate the substrate with beak, searching for hidden prey. For each species we recorded only the initial observation of an attempt or capture of a prey.

\section{Results}

\subsection{Abundance and sociality of species}

A total of 41 bird species were recorded within mixed flocks in the tecoma savanna. Among them, the most abundant in this habitat type were Xolmis irupero (Vieillot) ( $\mathrm{N}=377$ records), Pyrocephalus rubinus (Boddaert) $(\mathrm{N}=291)$ and Tyrannus melancholichus Vieillot $(\mathrm{N}=228)$, all of them from Tyrannidae (Table 1). However, Suiriri suiriri (N = 169 records), also from Tyrannidae, was present in most mixed flocks, while the participation of other species was smaller $(<50 \% ; \mathrm{N}=41$ mixed flocks; Table 1). Suiriri suiriri, Icterus cayanensis, and Sporophila leucoptera, were included in active mixed flocks for prolonged periods $(\mathrm{N}=10$ mixed flocks observed by $>30$ minutes, Table 1). Campylorhamphus trochilirostris (Burmeister), Elaenia sp., and Xenopsaris albinucha (Burmeister), also participated for prolonged periods, however, all of them were seldom present in mixed flocks (Table 1).

The species which were present in at least $40 \%$ of mixed flocks (Table 1) were analyzed for their frequency of participation in mixed flocks and to join intraspecific groups. Lepidocolaptes angustirostris (Vieillot) exhibited the highest rate of occurrence in mixed flocks $(33.5 \%$, $\mathrm{N}=30$ e counters), followed by Suiriri suiriri (20\%, $\mathrm{N}=105$ encounters, Figure 1). The other species analyzed showed smaller frequency of participation in joining mixed flocks: Icterus cayanensis (Linnaeus) 12\% $(\mathrm{N}=75)$, Sporophila leucoptera (Vieillot) $8 \%(\mathrm{~N}=89$; Figure 1). Groups of 2-4 Suiriri suiriri often foraged within mixed flocks, while lone individuals were not recorded ( $\mathrm{N}=40$ mixed flocks, Table 1). The other species were less gregarious, especially Lepidocolaptes angustirostris, which was often alone when foraging within mixed flocks ( $84 \%$ of records, $\mathrm{N}=19)$. Icterus cayanensis $(\mathrm{N}=19)$ and

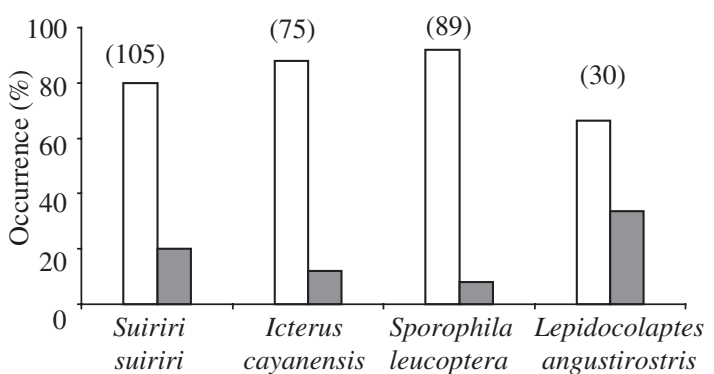

Figure 1. Sociality of species (occurrence $>40 \%$ of mixed flocks; 144 hours of survey). White column: solitary individuals or pure groups; gray: birds within mixed flocks. In brackets the sample size for each species.
Sporophila leucoptera $(\mathrm{N}=18)$ occurred within mixed flocks as lone individuals $(10.5 \%$ and $16.5 \%$, respectively), pairs $(52.5 \%$ and $39.0 \%$ ), and pure groups ( $37 \%$ and $44.5 \%$, Figure 2).

\subsection{Behavioral traits of species}

Among the species commonly present in mixed flocks, Suiriri suiriri foraged more often performing conspicuous maneuvers, like sally-glean, sally and surface maneuvers $(71 \%, \mathrm{~N}=230$ attempts of capture of a prey). In most cases $(80 \%) S$. suiriri attempted to capture a prey at the open crown of tecoma trees. On the other hand, species such as Icterus cayanensis $(\mathrm{N}=67)$, Lepidocolaptes angustirostris $(\mathrm{N}=61)$, and Picoides mixtus (Boddaert) $(\mathrm{N}=47)$ almost always $(>95 \%$ for all of them) employed surface maneuvers.

The mixed flocks moved conspicuously 16 times. Only once $S$. suiriri was not in the front position. Three times Picoides mixtus followed S. suiriri earlier, while each species Icterus cayanensis, Lepidocolaptes angustirostris, and Troglodytes aedon (Vieillot) did the same twice. In the other six movements, however, other different species followed $S$. suiriri earlier. In the absence of $S$. suiriri (two cases), mixed flock members followed Molothrus badius (Vieillot) or Icterus cayanensis.

Birds often gave contact calls while foraging within mixed flocks and only once no contact call was recorded. In the absence of S. suiriri (one case), M. badius and I. cayanensis gave contact calls continuously. However, while most species seldom gave contact calls, S. suiriri gave more than $75 \%$ of the contact calls recorded $(\mathrm{N}=360$, Figure 3$)$.

The play backs of the voices of Glaucidium brasilianum and Ramphastos toco stimulated eleven and six responses, respectively. Suiriri suiriri earlier approached the observer five times; Eupetomena macroura (Gmelin) four, while either Sporophila leucoptera or Thraupis sayaca (Linnaeus) twice. Another four species responded earlier only once (Figure 4). The responses to the simulations of predator voices consisted of loud vocalizations, flights over the tape recorder, besides potential attacks. Suiriri suiriri vocalized

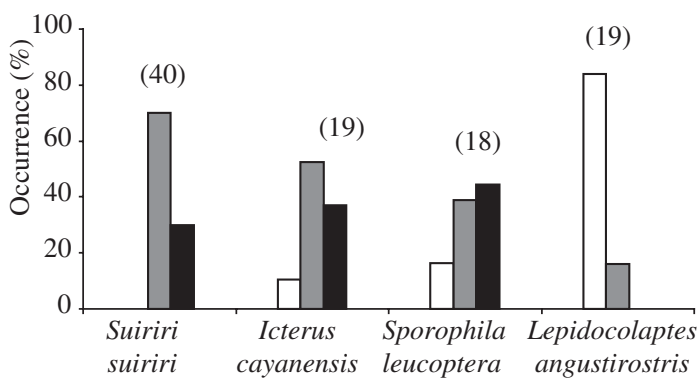

Figure 2. Group size of species while within mixed flocks (occurrence $>40 \%$ ). White column: solitary individuals; gray column: two individuals; black column: three or more individuals. In brackets the number of mixed flocks sampled for each species. 
Table 1. Species occurrence in mixed flocks, range of group size for each species ( $\mathrm{N}=41$ flocks), mean time within mixed flocks ( $\mathrm{N}=10$ flocks) and abundance of species, which participated in mixed flocks in the tecoma savanna (252 hours of census).

\begin{tabular}{|c|c|c|c|c|}
\hline Species & $\begin{array}{c}\text { Occurrence } \\
\text { in mixed } \\
\text { flocks }(\%) \\
\end{array}$ & $\begin{array}{l}\text { Number of } \\
\text { individuals }\end{array}$ & $\begin{array}{c}\text { Mean ( } \pm \text { sd) time } \\
\text { within mixed flocks } \\
\text { (minutes) }\end{array}$ & $\begin{array}{l}\text { Records in } \\
\text { census }\end{array}$ \\
\hline Suiriri suiriri & 98 & $2-6$ & $75 \pm 21$ & 169 \\
\hline Icterus cayanensis & 49 & $1-10$ & $60 \pm 23$ & 119 \\
\hline Sporophila leucoptera & 46 & $1-5$ & $60 \pm 21$ & 137 \\
\hline Lepidocolaptes angustirostris & 44 & $1-2$ & $41 \pm 16$ & 48 \\
\hline Picoides mixtus & 34 & $1-2$ & $50 \pm 17$ & 32 \\
\hline Schoeniophylax phryganophila (Vieillot) & 32 & 2 & $40 \pm 17$ & 48 \\
\hline Furnarius rufus (Gmelin) & 32 & $1-2$ & $44 \pm 17$ & 168 \\
\hline Tyrannus melancholicus & 29 & $1-2$ & $40 \pm 15$ & 228 \\
\hline Paroaria coronata (Miller) & 22 & $1-9$ & $44 \pm 25$ & 177 \\
\hline Volatinia jacarina (Linnaeus) & 22 & $1-4$ & $41 \pm 17$ & 149 \\
\hline Molothrus badius & 20 & $5-25$ & $50 \pm 35$ & 111 \\
\hline Piculus chrysochloros (Vieillot) & 17 & $1-2$ & $48 \pm 27$ & 20 \\
\hline Phacellodomus ruber (Vieillot) & 17 & 2 & $50 \pm 24$ & 86 \\
\hline $\begin{array}{l}\text { Coryphospingus cucullatus } \\
\text { (Statius Muller) }\end{array}$ & 15 & $1-2$ & $35 \pm 14$ & 38 \\
\hline Pyrocephalus rubinus & 12 & 1 & $45 \pm 17$ & 291 \\
\hline Troglodytes aedon & 12 & $1-2$ & $26 \pm 5$ & 46 \\
\hline Machetornis rixosus (Vieillot) & 12 & $2-3$ & $25 \pm 5$ & 82 \\
\hline Colaptes melanochloros & 10 & $1-2$ & $40 \pm 17$ & 21 \\
\hline $\begin{array}{l}\text { Poospiza melanoleuca } \\
\text { (d'Orbigny and Lafresnaye) }\end{array}$ & 10 & $1-2$ & $40 \pm 17$ & 27 \\
\hline Sporophila collaris (Boddaert) & 10 & $1-5$ & 30 & 32 \\
\hline Thraupis sayaca & 7 & 1 & 25 & 124 \\
\hline Xolmis irupero & 7 & 1 & $23 \pm 1$ & 377 \\
\hline Formicivora rufa (Wied) & 7 & $1-2$ & $40 \pm 17$ & 13 \\
\hline $\begin{array}{l}\text { Paroaria capitata } \\
\text { (d'Orbigny and Lafresnaye) }\end{array}$ & 7 & 2 & 30 & 34 \\
\hline Zonotrichia capensis (Statius Muller) & 7 & $1-2$ & $27 \pm 3$ & 19 \\
\hline Sporophila sp. & 7 & $3-12$ & $30 \pm 0$ & 11 \\
\hline Campylorhamphus trochilirostris & 5 & 1 & 90 & 7 \\
\hline Cyclarhis gujanensis (Gmelin) & 5 & 1 & $45 \pm 21$ & 21 \\
\hline Elaenia sp. & 5 & 1 & 60 & 18 \\
\hline Xenopsaris albinucha & 5 & 1 & 60 & 8 \\
\hline Phacellodomus rufifrons (Wied) & 5 & 2 & $23 \pm 1$ & 11 \\
\hline Sicalis flaveola (Linnaeus) & 5 & $6-24$ & 30 & 37 \\
\hline Sporophila caerulescens (Vieillot) & 5 & 1 & $22 \pm 1$ & 22 \\
\hline Cacicus solitarius (Vieillot) & 5 & $1-2$ & - & 10 \\
\hline Veniliornis passerinus (Linnaeus) & 2 & 1 & - & 2 \\
\hline Satrapa icterophrys (Vieillot) & 2 & 1 & 30 & 4 \\
\hline Camptostoma obsoletum (Temminck) & 2 & 1 & 30 & 3 \\
\hline Serpophaga subcristata (Vieillot) & 2 & 1 & - & 2 \\
\hline Sporophila hypoxantha Cabanis & 2 & 2 & - & 6 \\
\hline Gnorimopsar chopi (Vieillot) & 2 & 4 & - & 14 \\
\hline Carduelis magellanicus (Vieillot) & 2 & 2 & 30 & 2 \\
\hline
\end{tabular}

loudly, while hummingbirds flew toward the tape recorder. Suiriri suiriri earlier responded to two of six playbacks, one of G. brasilianum and another of $R$. toco, performed when mixed flocks were observed. Colaptes melanochloros earlier responded once, and once, birds flew away. Birds exhibited no response to two simulations.
We recorded 16 agonistic interactions involving mixed flocks species: 14 intraspecific and only two interspecific. In nine interactions, one individual chased away an approaching conspecific. Icterus cayanensis performed most aggressions, mainly when groups of this species were larger (pers. obs.). Only twice, individuals 


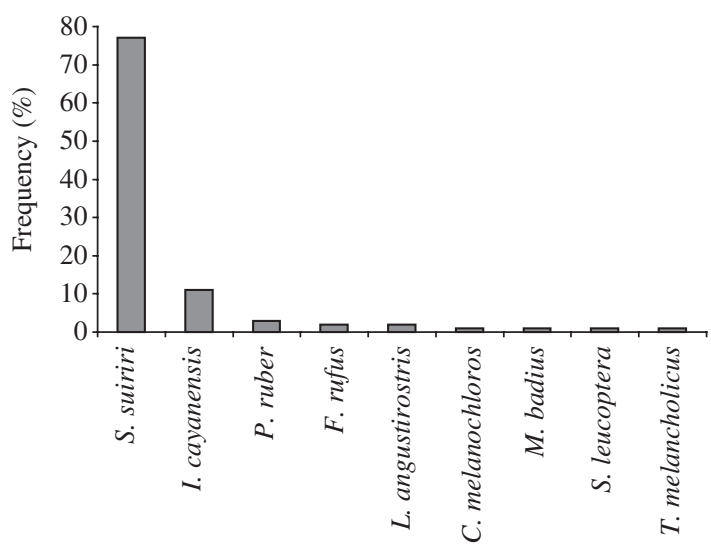

Figure 3. Contact calls given $(\mathrm{N}=360)$ by species while within mixed flocks in the tecoma savanna $(\mathrm{N}=17$, 10 minutes samples).

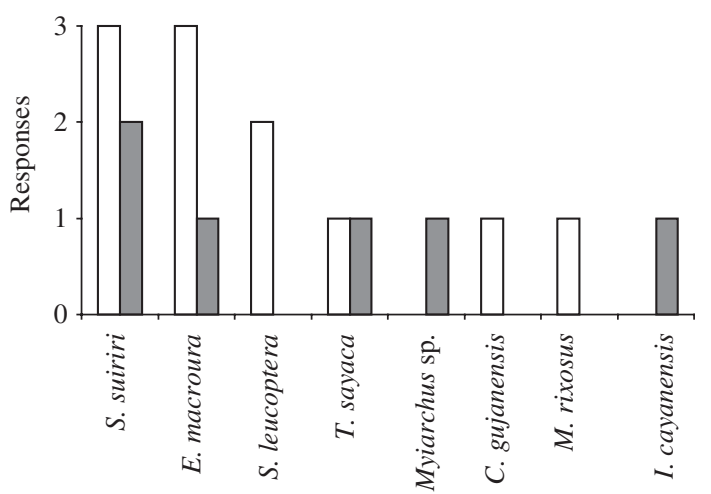

Figure 4. Number of responses to simulation of predator's vocalization. White column: vocalization of Glaucidium brasilianum; gray column: vocalization of Ramphastos toco.

of $S$. suiriri fought each other, and just once did it chase way an individual of Paroaria coronata (Table 2).

\section{Discussion}

In the strictest sense, nuclear species are probably not needed for flock formation. On the other hand, nuclear species may be important for the maintenance of flock cohesion. This is supported by the observation that flocks without nuclear species break apart rapidly (Powell, 1979). The attraction of nuclear species may be nothing more than a sharp focus for movement and direction (Austin and Smith, 1972), which results from the conspicuousness of a number of active, vocal individuals foraging in close proximity. In fact, many studies have emphasized the conspicuous traits of nuclear species. In most of them, the regularity of communication by contact calls and acrobatic foraging maneuvers have been assumed as the traits more often exploited by other species to be aware about flock members position and
Table 2. Agonistic interactions in mixed flocks in the Tecoma Savanna

\begin{tabular}{|c|c|c|c|c|c|c|c|c|c|}
\hline \multirow{2}{*}{$\begin{array}{l}\text { Aggressor } \\
\text { species }\end{array}$} & \multicolumn{9}{|c|}{ Chased species } \\
\hline & 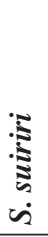 & 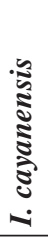 & 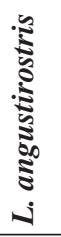 & $\underset{5}{\stackrel{5}{S}}$ & 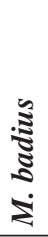 & $\underset{5}{5}$ & 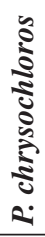 & 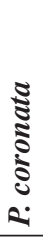 & 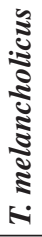 \\
\hline S. suiriri & 2 & - & - & - & - & - & - & 1 & - \\
\hline I. cayanensis & - & 4 & - & - & 1 & - & - & - & - \\
\hline L. angustirostris & - & - & 2 & - & - & - & - & - & - \\
\hline F. rufus & - & - & - & 1 & - & - & - & - & - \\
\hline M. badius & - & - & - & - & - & - & - & - & - \\
\hline F. rufa & - & - & - & - & - & 1 & - & - & - \\
\hline P. chrysochloros & - & - & - & - & - & - & 1 & - & - \\
\hline P. coronata & - & - & - & - & - & - & - & 1 & - \\
\hline T. melancholicus & - & - & - & - & - & - & - & - & 1 \\
\hline
\end{tabular}

movements (Sullivan, 1984a,b; Monkkonen et al., 1996). Group members of social species often give contact calls, while less social or even solitary species tend to be silent. Therefore, the last ones may benefit by exploiting the communication of social species to avoid dispersion and isolation (Sullivan, 1984a,b; Dolby and Grubb, 1999). In the the tecoma savanna, one of the most conspicuous species was Suiriri suiriri. Unlike most other species, S. suiriri foraged performing acrobatic maneuvers within the crown of tecoma trees. Thus, $S$. suiriri was at a prominent position in relation to the other species, which foraged closer to the ground. Moreover, foraging groups of 2-4 S. suiriri were common and exhibited intense communication by contact calls. In principle, for birds foraging silently among grasses, potentially, the noisy groups of $S$. suiriri moving acrobatically some meters above were a clear reference. Also, $S$. suiriri moved early during mixed flock displacements, exhibited low interspecific aggressiveness and high alertness.

Besides being conspicuous, a nuclear species is often among the commonest ones (Hutto, 1994). Species with low densities or restrained to particular habitats are seldom present in mixed flocks. Another limitation is the size of home range of a species. Birds whose territory size is smaller than that of most mixed flock participants may be within mixed flocks during short periods (Powell, 1985). As $S$. suiriri was among the most abundant species in the tecoma savanna and, apparently, was not restricted to particular patches of vegetation, it is highly likely to be a mixed flock member (Hutto, 1994). In fact, the prolonged periods of permanence foraging within mixed flocks suggest that $S$. suriri was not restrained either by a small home range or particular habitats.

Other potential nuclear species, Icterus cayanensis and Molothrus badius, besides being intraspecifically 
gregarious, occurred for prolonged periods within mixed flocks. Furthermore, in the only mixed flock in which $S$. suiriri was absent, these species often gave contact calls, as well as being in the front during mixed flocks movements. However, both species seldom occurred within mixed flocks (Table 1), apart from foraging cryptically, and were less alert. Also, M. badius and I. cayanensis always followed S. suiriri when within the same mixed flock. Most other mixed flock members foraged solitarily, silently and closely focusing the vegetation. Apparently, this pattern of foraging behavior, at least, reduces the perception of flock partners, and predators as well (Munn and Terborgh, 1979; Sullivan, 1984a,b; Ragusa-Netto, 2002).

One potential benefit associated with flock foraging is that an individual within a group may discover and use widely scattered, patchily distributed food more efficiently than if it had foraged independently. In fact, feeding benefits are expected if insects are flushed by flock mates or due to copying behavior (Powell, 1985). In either case, a species would require the presence and close proximity of another species that employed a specific kind of foraging behavior (Krebs, 1973; Munn and Terborgh, 1979). Although the analysis on specific association between foraging species was beyond the scope of this study, during the observations on foraging tactics, no interaction suggested that a species foraged focusing another one, which might provide increased chances of prey capture. Despite being acrobatic and very conspicuous, the foraging maneuvers employed by Suiriri suiriri, apparently attracted no other bird species to forage in close proximity to them. On the contrary, as mentioned above, $S$. suiriri typically foraged within the crown of tecoma trees, while most other species closely foraged on or close to the ground. Therefore, as found for most other studies, the organization of Neotropical bird mixed flocks is unrelated to foraging advantages, as well as the role of nuclear species being unrelated to feeding benefits (Hutto, 1994).

Bird cohesion in mixed flocks provides shelter due to the dilution and confusion effect (Hamilton, 1971). Also, bird cohesion reduces predation risk due to the 'many eyes effect', in which the combination of vigilance efforts enhances the perception of predators. Thus, birds may reduce personal time devoted to scan for predators and, conversely, employ more time in foraging activities (Pulliam, 1973; Powell, 1974). Gaddis (1980) pointed out the importance of alertness and communication by alarm calls as the major trait of nuclear species for mixed flock cohesion. Some studies on Neotropical mixed flocks have shown the existence of anti-predatory mechanisms in the nuclear species, which are related to an earlier perception of raptors (Munn and Terborgh, 1979; Alves and Cavalcanti, 1996; Ragusa-Netto, 2000, 2002). Because such birds are highly alert, they spot approaching raptors earlier, as well as being aware of fellow group members giving alarm calls (Sullivan, 1984a,b; RagusaNetto, 2000; 2002). Suiriri suiriri foraged scanning about and capturing prey in the air or on the leaf surface. Such foraging tactic in which $S$. suiriri focuses a wide field to detect prey, potentially provides earlier perception of raptors (Munn and Terborgh, 1979). On the other hand, most other species closely inspect the substrate. As the reduction of predation risk is among the major features for bird cohesion in mixed flocks (Gaddis, 1981; Ragusa-Netto, 2000; 2002), the enhanced alertness exhibited by $S$. suiriri besides their other conspicuous traits, may at least partly explain the permanence of this species in the front of mixed flocks while foraging in the tecoma savanna.

Acknowledgements - We are grateful to Edílson Silva, Rosemar Santos, Rosana Costa, and Josefa de Oliveira for the logistical support at BEP/UFMS. The constructive comments of an anonymous reviewer improved an earlier version of this paper. Financial support was provided by FUNDECT, CNPq and PROPP/UFMS

\section{References}

ALVES, MA. and CAVALCANTI, RB., 1996. Sentinel behavior, seasonality, and the structure of bird flocks in Brazilian savanna. Ornit. Neotr., vol. 7, no. 1, p. 43-51.

AUSTIN, GT. and SMITH, EL., 1972. Winter foraging ecology of mixed insectivorous bird flocks in oak woodland in southern Arizona. Condor, vol. 74, no. 1, p. 17-24.

BERNER, TO. and GRUBB, TC., 1985. An experimental analysis of mixed-species flocking in birds of deciduoud woodland. Ecology, vol. 66, no. 4, p. 1229-1236.

BIBBY, CJ., BURGESS, ND. and HILL, D., 1993. Bird Census Techniques. 3 ed. Cambridge: Academic Press. 257 p.

DOLBY, AS. and GRUBB Jr., TC., 1999. Functional roles in mixed-species foraging flocks: a field manipulation. $A u k$, vol. 116, no. 2, p. 557-559.

GADDIS, PK., 1980. Mixed flocks, Accipiters, and antipredator behavior. Condor, vol. 82, no. 2, p. 348-349.

GOODALE, E. and KOTAGAMA, SW., 2005. Testing the roles of species in mixed-species birds flocks of a Sri Lankan rain forest. J. Trop. Ecol., vol. 21, no. 6, p. 669-676.

GREIG-SMITH, PW., 1978. The formation, structure and function of mixed-species insectivorous bird flocks in west African savanna woodland. Ibis, vol. 120, no. 3, p. 284-297.

HAMILTON, WD., 1971. Geometry for the selfish herd. J. Theor. Biol., vol. 31, no. 2, p. 295-311.

HINO, T., 1998. Mutualistic and commensal organization of mixed foraging flocks in a forest of Western Madagascar. J. Avian. Biol., vol. 29, no. 1, p. 17-24.

HOGSTAD, O., 1988. Advantages of social foraging of willow tits Parus montanus. Ibis, vol. 130, no. 2, p. 275-283.

HUTTO, RL., 1994. The composition and social organization of mixed-species flocks in a tropical deciduos forest in western Mexico. Condor, vol. 96, no. 1, p. 105-118.

KREBS, JR., 1973. Social learning and the significance of mixed-species flocks of chickadees (Parus spp). Can. J. Zool., vol. 51 , no. 12 , p. $1275-1288$. 
MÖNKKÖNEN, M., FORSMAN, JT. and HELLE, P., 1996. Mixed-species foraging aggregations and heterospecific attraction in boreal bird communities. Oikos, vol. 77, no. 1, p. $127-136$.

MOYNIHAN, M., 1962. The organization and probable evolution of some mixed species flocks of neotropical birds. Smith. Misc. Col., vol. 143, no. 1, p. 1-140.

MUNN, C. and TERBORGH, JW., 1979. Multi-species territoriality in neotropical foraging flocks. Condor, vol. 81, no. 2 , p. $338-347$.

OLIVEIRA, AKM., 1993. Alguns aspectos de estrutura e comparação entre três paratudais, no Pantanal do Miranda. São Carlos: Universidade Federal de São Carlos. [Dissertação de Mestrado]

POTT, A. and POTT, VJ., 1994. Plantas do Pantanal. Corumbá: Embrapa SPI. 320 p.

POWELL, GVN., 1974. Experimental analysis of the social value of flocking by starlings (Sturnus vulgaris) in relation to predation and foraging. Animal Behav., vol. 22, no. 2, p. 501-505.

-, 1979. Structure and dynamics of interespecific flocks in a neotropical mid-elevation forest. Auk, vol. 96, no. 2, p. 375390 .

-, 1985. Sociobiology and adaptative significance of heterospecific foraging flocks in the neotropics. In BURCKLEY, PA. (Ed.). Neotropical Ornithology. Ornit. Monogr., vol. 36, p. 713-732.

-, 1989. On the possible contribution of mixed species flocks to species richness in neotropical avifaunas. Behav. Ecol. Sociobiol., vol. 24, no. 6, p. 387-393.

PULLIAM, H.R., 1973. On the advantages of flocking. J. Theor. Biol., vol. 38, no. 2, p. 419-422.
RAGUSA-NETTO, J., 2000. Raptors and "campo-cerrado" bird mixed flock led by Cypsnagra hirundinacea (Emberizidae: Thraupinae). Rev. Bras. Biol. = Braz. J. Biol., vol. 60, no. 3, p. 461-467.

-, 2002. Vigilance towards raptors by nuclear species in bird mixed flocks in a Brazilian savannah. Stud. Neotr. F. Env., vol. 37, no. 3, p. 219-226.

RAND, AL., 1954. Social feeding behaviour of birds. Field. Zool., vol. 36, no. 1, p. 1-71.

RENSEM, JV. and ROBINSON, SK., 1990. A classification scheme for foraging behavior of birds in terrestrial habitats. Stud. Avian. Biol., vol. 13, no. 1, p. 144-160.

SICK, H., 1997. Ornitologia Brasileira. Rio de Janeiro: Nova Fronteira. 912 p.

SORIANO, BMA., 1997. Boletim agrometereológico: 1986-1996 (Fazenda Nhumirim). Corumbá: Embrapa. (Circular Técnica 3).

STOTZ, DF., 1993. Geographic variation species composition of mixed flocks in lowland humid forest in Brazil. Pap. Avul. Zool., vol. 38, no. 4, p. 61-75.

SULLIVAN, KA., 1984a. The advantages of social foraging in Downy woodpeckers. Anim. Behav., vol. 32, no. 1, p. 16-22.

-, 1984b. Information exploitation by downy woodpeckers in mixed species flocks. Behaviour, vol. 91, no. 4, p. 294-311.

THIOLLAY, JM. and JULLIEN, M., 1998. Flocking behaviour of foraging birds in a neotropical rain forest and antipredator defence hypothesis. Ibis, vol. 140, no. 3, p. 382-394.

WAITE, TA. and GRUBB Jr., TC., 1988. Copying of foraging locations in mixed-species flocks of temperate-deciduos woodland birds: an experimental study. Condor, vol. 90, no. 1, p. $132-140$.

WINTERBOTTOM, JM., 1949. Mixed bird parties in the tropics, with special reference to Northern Rhodesia. Auk, vol. 66 , no. 3 , p. $258-263$. 